\title{
Social capital for rural revitalization in China: A critical evaluation on the government's new countryside programme in Chengdu
}

(A paper accepted by Land User Policy)

\author{
Bin $\mathrm{Wu}^{1 *}$ and Linghui $\mathrm{Liu}^{2 *}$
}

1. Dr. Bin Wu, Nottingham University Business School, Nottingham, UK

bin.wu@nottingham.ac.uk

2. Dr. Linghui Liu, University of Electronic S\&T of China, Chengdu, China, liulinghui2005@163.com

\section{Abstract}

In the context of urbanisation and decline of its countryside in the $21^{\text {st }}$ century, the Chinese government has initiated a campaign namely "building a socialist new countryside" in 2006 which is now renamed as "rural revitalisation”. Bringing together social capital, government intervention and other capital, we argue that rural revitalisation can be viewed as a process of the interaction between land transfer and community building leading to multiple gains of all stakeholders. Given the predomination of top-down government intervention and external capital investment in its campaign, this paper sheds new light on social capital in terms of not only mobilising community members' participation, but also reaching a balance with interests of government and other stakeholders. The importance of social capital can be illustrated from critical evaluation on governmental pilot projects in the suburban zone of Chengdu, a model municipal in China in urban-rural integration. In particular, this paper aims to address the following questions: How does social capital engage and contribute to rural restructuring for sustainable rural livelihoods? What role can social capital play in the decision making of land transfer and community building? This paper contributes to rural revitalisation and land use debates in three aspects. Firstly, we post a triangular model by bringing together government intervention, social and other capital to emphasize the interwoven nature of the relationship between land transfer and community building for better understanding of the intrinsic dynamics within the communities and their interests interfaced with external stakeholders. Secondly, with respect to the impact of land transfer on sustainable livelihoods, we propose an evaluation framework to account and compare

\footnotetext{
* Responding authors: Dr. Bin Wu, Nottingham University Business School, Nottingham, UK, bin.wu@nottingham.ac.uk; Dr. Linghui Liu, University of Electronic S\&T of China, Chengdu, China, liulinghui2005@163.com
} 
the roles of social capital against government intervention and other conditions in land transfer decision making. Thirdly, applying the above framework to sample villages, we identify three types of rural restructuring: government-led, farmer self-organising, and returned entrepreneur-oriented. Policy implications and further research direction are discussed.

Key words: Rural revitalisation, land transfer, social capital, government intervention, Chengdu, China

\section{Introduction}

The impressive achievements of China's urbanisation over the past two decades have been associated with a decline of its countryside referring to a process of the outflows of labour, talents, land, finance and investment from rural to urban areas, resulting in brain drains, depopulation and spread of hollowed villages, farmland abandoned, and left-behind population (Liu, et al., 2010; Ye, 2009; Long, et al. 2016, Liu, 2018).

The phenomenon of rural decline is not limited to China but a common experience in both developed and developing world (Woods, 2005; Liu and Li, 2017; Li, et al., 2019). Whilst many scholars attribute the decline as an inevitable process or consequences of urbanisation, others may view it as a part of the capitalist world system (de Haas, 2010). As a result, there are different approaches to the reverse process of rural decline. From the perspective of social capital, this paper draws attention to the relationship between social capital, government intervention and other capital in order to understand the intrinsic dynamics, tensions and the balance between multiple stakeholders in the process of rural revitalisation.

The value of social capital for rural revitalisation can be illustrated from a case of China as for over a decade the Chinese government has initiated a national campaign of so-called as "building a socialist new countryside" (BSNC) which was renamed as "rural revitalisation" in 2017. The aims of the programme include: advanced production, a comfortable living standard, a civilized lifestyle, clear and tidy villages, and effective governance. As an "intentionally vague but holistic policy framework" (Ahlers and Schubert 2009: 57), it leaves a space for different interpretations and practices at the local level. When overwhelming attention is paid to the reverse flow of key resources, including: physical, financial, human capitals from urban to rural areas, we argue that social capital, a key dimension of rural community cohesion, cannot be ignored. 
The necessity of social capital can be understood from three challenges facing rural revitalisation in China. Firstly, rural revitalisation calls for a balance and interface between top-down intervention and bottom-up development in order to better account the different interests of multiple stakeholders and rural community members in particular (Li, et al., 2014; Li, et al., 2019; Zhou, et al. 2019). Whereas overwhelming attention is currently paid to how to improve the governmental plans and designs, a systematic examination of the relationship between social and other capital is lacking, a key to understanding the intrinsic dynamics and innovative potential within rural communities. Secondly, rural revitalisation involves a process of land transfer from individual households to new economic bodies (family farms, farmer cooperatives or agribusiness firms) which is heavily dependent upon the participation and consent among all village members. Given the dysfunction of many village collective organisations across China, social capital is a key variable influencing the success or failure of land transfer. Thirdly, rural revitalisation cannot be successful unless the shortage of talents can be resolved. In this regard, social capital offers a useful lens to observe and understand the conditions of reversed migration (Wu and Liu, 2019).

This paper aims to address the role of social capital in rural revitalisation via two research questions: How does social capital engage and contribute to rural restructuring, a process of redistribution and reallocation of various resources for sustainable rural livelihoods? What role can social capital play in the decision-making of land transfer and community building? Accordingly, this paper intends to make a contribution to rural revitalisation debates from three aspects: A) a triangular model by bringing together government intervention, social and other capital for better understanding the intrinsic dynamics within the communities and their interests interfaced with external stakeholders; B) an evaluation framework to reveal the role of social capital against government intervention and other conditions in land transfer decision making; C) applying the evaluation framework to analysis and compare differences of rural restructuring practices among sample villages.

The geographic location of evidence collection for this paper is based upon the suburban zone of Chengdu, which may present a new exploration of rural development in large cities of China where local governments and urban entrepreneurs have interests and resources to engage with rural restructuring. This paper is organised into six parts. The next section will review literature of rural restructuring in the context of institutional environment, government intervention and reverse flows of various capital. It is followed 
by an evaluation framework based upon a triangular relationship between government intervention, social and other capitals. Section 4 provides a background about the government's pilot projects in Chengdu whilst Sections 5 presents results of data analysis based upon our fieldwork in 10 sample villages. This paper ends with a discussion and conclusion in Section 6.

\section{Literature review}

In the context of globalisation and urbanisation since the late $20^{\text {th }}$ century, the term rural restructuring or revitalisation is increasingly popular to cope with challenges from a large scale of rural-urban migration, brain drains, and rural decline (Liu, et al., 2016; Liu and Li, 2017; Li, et al., 2019). In relation with different understandings on the causes for rural decline, unsurprisingly, there are different approaches to rural revitalisation.

For the neo-classic school of thought, rural development/revitalisation is a process of optional allocation of production factors (capital, land and labour) to the benefit of both sending (rural) and receiving (urban) societies. This is because the re-allocation of labour from rural, agricultural areas to urban, industrial sectors is accompanied with capital flows from the labour scarce to the capital-scarce sending society (Massey et al., 1998).

In contrast, neo-Marxist perspective views the above process is uneven in terms of the reallocation and redistribution of valuable human and material capital across spatial (inter-region) and sector (rural vs. urban, agricultural vs. industrial) borders, leading to a vicious cycle: migration -- more underdevelopment -- more migration (de Haas, 2010: 234-235). Such negative feedback mechanisms have profound and severe impacts on rural communities, including "the disruption of traditional kinship systems and care structures" (King and Vullnetari, 2006), the loss of community solidarity or the undermining of their "sociocultural integrity" (Hayes, 1991), and the breakdown of traditional institution regulating, village life and agriculture (de Haas, 1998).

Rejecting the simplistic and homogenous, de Haas draws our attention to the heterogeneity of reallife migration-development interaction and its impact on the sending (rural) communities as rural migrants "tend to maintain close links with their communities of origin over much longer periods than has previously 
been assumed, [and also] the development contribution of migration is not necessarily linked to the return of migrants" (de Haas, 2010: 246).

Contrary to linear relationship between urbanisation and the decline of countryside, many scholars draw our attention to a new phenomenon of counter-urbanization referring to two types of urban-rural migration: decentralization, migration from towns and cities to adjacent rural areas; and deconcentration, inter-regional migration from metropolitan areas to rural districts (Woods, 2005:74). The significance of counter-urbanization is not merely broadening our view on rural-urban migration from one-way to two ways, but initiates a debate of rural restructuring, referred to "the reshaping of social and economic structures in rural areas in the late twentieth century and early twenty-first century" (Woods, 2009). The key characteristics of rural restructuring is related to "strong identification in service class culture with the countryside and the ideals of rural idyll”. (Woods, 2005: 85-86).

Rural restructuring involves "the allocation and management of the critical resources including human, land and capital and realise the structure optimization and function maximum of rural development system" (Long, et al., 2016: 394-395). Further to the conditions of successful rural restructuring, according to $\mathrm{Li}$, et al. (2019), strong social capital is important as it can "support entrepreneurship in new activities with access to credits, labour, human capital, external markets and external knowledge for learning and innovation".

Interrelated with other types of capital, social capital plays a key role in bringing together all people and resources for meaningful work. Regarding the role of social capital in rural restructuring, sustainable rural livelihoods offers a useful concept to understand and analyse the flows and links between different capitals in the context of the vulnerability of rural people whose livelihoods are affected by critical trends (population, economic, technological changes), shocks (e.g. health, natural, economic, conflict) and seasonality (of price, production, and non-farm employment) (DFID, 1999). A sustainable livelihoods framework has been developed to understand how livelihood resources (or capitals/assets) are linked through institutional processes and organisational structures, with livelihoods strategies and sustainable livelihood outcomes (Scoones, 2009).

However, social capital may mean different things to different people. For Putnam (1995: 67), social capital can be viewed as "features of social organisation such as networks, norms and social trust that 
facilitate coordination and cooperation for mutual benefit". Alone this line, social capital is important because "mutual trust and reciprocity lower the costs of working together" (DFID, 1999). With respect to collective social capital, furthermore, Putnam (2000) distinguishes between bonding social capital and bridging social capital: "bonding social capital occurs between likeminded people and, hence, typically among those with strong ties, while bridging social capital occurs between less likeminded individuals and, therefore, mainly among those with weak ties" (Teilmann, 2012: 460).

Viewing the community (rather than individuals, households, or the state) as "the primary unit of analysis", furthermore, Woolcock and Narayan (2000) distinguishes social capital and economic development into four perspectives: the communitarian view (local organisations); the networks view (bonding and bridging community ties), the institutional view (social capital as the product of the political and legal institutions), and the synergy view (community networks and state-society relations). In particular, Woolcock and Narayan (2000:243) emphasises that "social capital does not exist in a political vacuum", which can be used to promote or to undermine the public good.

Moving to the debate of rural restructuring/revitalisation in China, Su (2009: 8) raises an important question related to the government-led rural revitalisation: "how to assess, strengthen, and tap into local capacities that hold the greatest promise for revitalization in various Chinese rural communities?" For many, rural restructuring is a process of "village modernisation" to upgrade housing, infrastructure and access to public services (Looney, 2015: 915-916). Along this line, according to Ahlers (2015: 135-137), one of the driving forces behind rural restructuring is "the desire to 'free' land for commercial allocation" and local governments "strongly endorsed those modes of land intensification of agricultural production".

Beyond the narrow perspective on physical and financial capital, however, rural restructuring contains a dimension of community building to ensure the consent, participation and support from the majority, if not all, of the villagers. In this regard, different locations may have different practices or "models". For instance, the core of "Ganzhou model" is the establishment of "peasant councils" to ensure village renovation programme is "transparent, democratic and responsive to peasant interests" (Looney, 2015: 921) whilst the community-based rural residential land consolidation and allocation practices are characterised by self-organised rural planning, democratic decision-making and endogenous institutional innovation (Li et al., 2014). 
The key for the initiative and success of the community building, however, is largely dependent upon the leadership which is not always available within rural communities. To cope with this challenge, some local governments (e.g. Nan'an county of Fujian Province) sought for successful migrant entrepreneurs in urban areas and recruited them as village party secretaries, in order to fully use their migration experiences, business skills and business network with external investors (Alters and Schubert, 2015: 389). Along the same line, both Thøgersen (2011) and Lan et al (2014) identify the positive role of external NGOs through the "partnership of the community with external public and private institutions, corporations, scholars and NGOs.... in order to gain capital and investment, capacity building, education and training, and technical, business and financial advice and support" (Lan, et al., 2014:398).

To conclude, rural restructuring in China contains two interwoven processes: land transfer for sustainable rural livelihoods, and community building for better participation, share and fair distribution of village development. The rural restructuring can hardly be successful without the mobilisation and balance of various resources or capitals (e.g. natural, physic, finance, human) which is largely dependent upon both government intervention/police, and social capital. Comparing with the research on the conditions (other capital) and the government's role in resource allocation and distribution, less is known about how social capital engage and contribution to rural revitalisation, an important condition for successful land transfer and community building. This paper attempts to tackle this gap through an evaluation of the governmentled programme in Chengdu.

\section{Research design, analysis framework and hypotheses}

In the context of China, we define rural revitalisation as a process of interaction between land transfer and community building, leading to sustainable rural livelihoods for all at village level. Interconnecting with government's role in resource allocation and distribution, in particular, we assume that social capital plays a key role in mobilising and coordinating village members, leading to a successful process of community building and land transfer for effective attraction and use of other capitals. The term land transfer here denotes the process of the reallocation and redistribution of collective land (farmland, residential and nonagricultural land) within and beyond village boundaries for sustainable livelihoods and well-being improvement. The term community building here refers to a process of the development and enhancement of collective identity, value, vision and confidence for all village members to participate in collective 
decision making of land transfer, and actions to respond to various challenges and opportunities internally and externally. In facing challenges and opportunities from urbanisation, land transfer and community building cannot be successful without joint participation and contribution from both government and social capital not only because both are related to the changes of attitudes, perceptions and behaviours of individual village members in land use decision making, but because they also influence the inflow and use of other capitals.

For the purpose of evaluation of government-led rural revitalisation projects, the role of government and social capital in land transfer and community building can be examined from the local context or conditions of resource endowments (other capitals), livelihood strategies (referring to activity choices for community members), and outcomes (e.g. income, health and sanitation standards, access to the public services, capacities to cope with market waves and uncertainties, and participatory rates of land transfer and share of responsibility of village development). Figure 1 illustrates an evaluation framework for social capital, rural restructuring and sustainable livelihoods which include a number of indicators for livelihood strategies and outcomes.

Figure 1: Social capital, rural restructuring and sustainable livelihoods: An evaluation framework

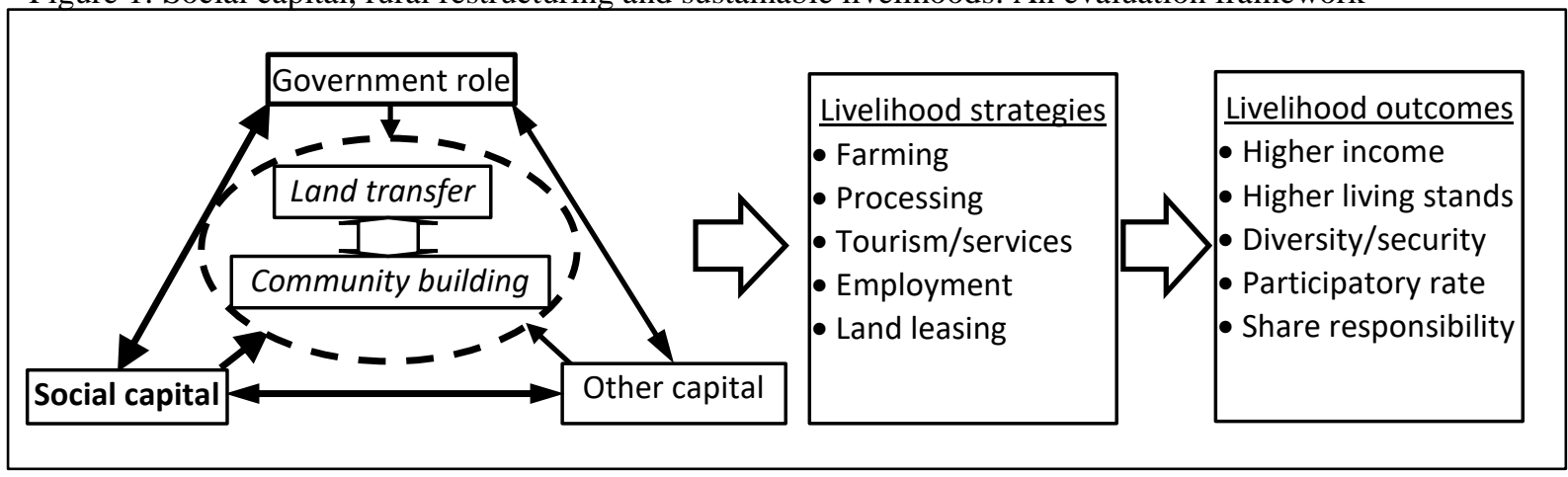

Table 1 provides a set of working definitions and indicators for observing and measuring social and other capital. Social capital is comprised of two types: bonding social capital refers to trust and common interests among village members while bridging social capital denotes mutual trust and collaborative relationship with individuals outside of villages, including those who are emigrants from the village (e.g. migrant workers or university graduates). For other types of capital, two or three sub-dimensions are listed for the purpose of empirical observation. 
Table 1 Definitions of social and other capital

\begin{tabular}{llll}
\hline Capital & \multicolumn{1}{c}{ Sub-dimension } & \multicolumn{1}{c}{ Definition } & \multicolumn{1}{c}{ Indicators } \\
\hline Social & Bonding & Trust/common interest within villages & Cooperative, shareholders, shared duties \\
& Bridging & Mutual trust with individuals outside & Partnership with external investors \\
\hline Physical & Geographic location & Service function to urban markets & Zone and distance to urban town centre \\
& Natural resources & Forestry, ecosystem services & Forestry, drinking water protection \\
& Transport & Access to transport network & Highway, public bus services \\
\hline Financial & Government & Government financial support & Amount of gov. funding \\
& Bank loan & Bank's discount loan & Amount of bank loan \\
& External & Investment outside of villages & Amount of investment \\
& Internal & Internal investment from villagers & Amount of investment \\
\hline Human & Education & Level of education & Number of HE students \\
& Labour & Rural-urban labour migration & No. of labour migrants \\
& Entrepreneur & Family farm and new entrepreneurs & No. entrepreneurs \\
\hline Culture & Historic heritage & Traditional crafts & Cage waving \\
& Tourism attractiveness & Religious or special places & Famous Buddhism Temples \\
\hline
\end{tabular}

In connection with research questions at the beginning of this paper, we pose the following hypotheses for empirical data analysis. For the first question regarding how social capital is engages with and contributes to rural restructuring, we assume that there is a triangular relationship between government, social and other capitals existing in all pilot projects. In other words, the triangular model can be applied to observe and interpret successful practices in rural restructuring.

For the second question on what particular role social capital can play in the decision making of land transfer and community building, we assume that there are three channels or pathways in project practices. Firstly, government-led process, referring to the initiatives made and determining role played by government agencies, leading to an enhancement of social capital among village members to catch/match external resources/opportunities (H1). Secondly, farmer self-initiative and organising process results in upgrading social capital for project design and implementation with less involvement of government intervention in the initiative stage $(\mathrm{H} 2)$. Thirdly, returned entrepreneur-oriented process via bridging social capital leads to the better use of local land resources and government support (H3).

The framework and hypotheses above provide a base for us to develop a critical evaluation on a government-led new countryside programme in the suburban zone of Chengdu. We have selected Chengdu for the empirical study due to following reasons. Firstly, compared with other villages in traditional agriculture or remote zones, the influence of urbanisation on the reallocation of rural land in the suburban zone is easier to observe and measure. Secondly, not limited to the land transfer, we are concerned about multiple involvement and the balance between internal members and external investors, to which suburban 
zone is an ideal location to conduct empirical research at the current stage. Thirdly, the emphasis on a balance development between rural and urban sectors has been adopted by Chengdu Municipal Government since it was appointed as a national experiment city by the central government a decade ago (Chen and Gao, 2011). For this paper, fieldwork was taken in 10 villages in the suburban zone of Chengdu Municipal in October 2015 in order to observe the latest development of government policies as well as collecting fresh experiences from villagers and external participants in those villages.

\section{Rural revitalisation in Chengdu: Background and fieldwork}

Chengdu is the capital of Sichuan Province in southwest China. Located in the western Sichuan Basin, the area of Chengdu Municipal or greater Chengdu (thereafter Chengdu) is $12,121 \mathrm{~km}^{2}$, of which plain areas account for $40.1 \%$, hilly areas, $27.6 \%$ and the remaining $32.3 \%$ by mountainous topography. Chengdu is comprised of 10 districts, 10 counties with a total population of 14,298 million (by 2014) distributed through three-tiers: Chengdu metropolis at the first, the periphery of the Metropolis at the second, and remote area at the third (Map 1). The suburban zone in this paper refers to rural areas located in the second and third tiers which are comprised of 206 townships and 1922 administrative villages.

Urbanisation in Chengdu has experienced an acceleration from $34.1 \%$ in 2000, $65.5 \%$ in 2010 jumping to $70.4 \%$ in 2014, which $15.6 \%$ higher than the national average (CDSB, 2001, 2011, 2015). In response to job opportunities in urban areas, the number of rural labour migration in Chengdu has increased from 1.55 million in 2008 to 2.17 million in 2014 , and the share of migratory labourers in the total of rural labour forces increased from $48.1 \%$ to $51.6 \%$ in the same period (CDSB, 2009, 2015). As a result, the geographic distribution of Chengdu's population between the three tiers have changed from $27.0 \%$ (first tier), $30.5 \%$ (second tier) and $43.5 \%$ (third tier) in 2005 to $31.1 \%, 30.8 \%$ and $39.1 \%$ in 2014 respectively (in hukou registration term). As a result of urbanisation and the large scale rural-urban migration, annual net income of rural residents in Chengdu has more than quadrupled from 2,926 yuan per capita in 2000 to 14,478 yuan per capita 2014 which is $46.4 \%$ higher than national average (CDSB, 2015). 
Map 1: Distribution of three tiers and sample villages in Chengdu

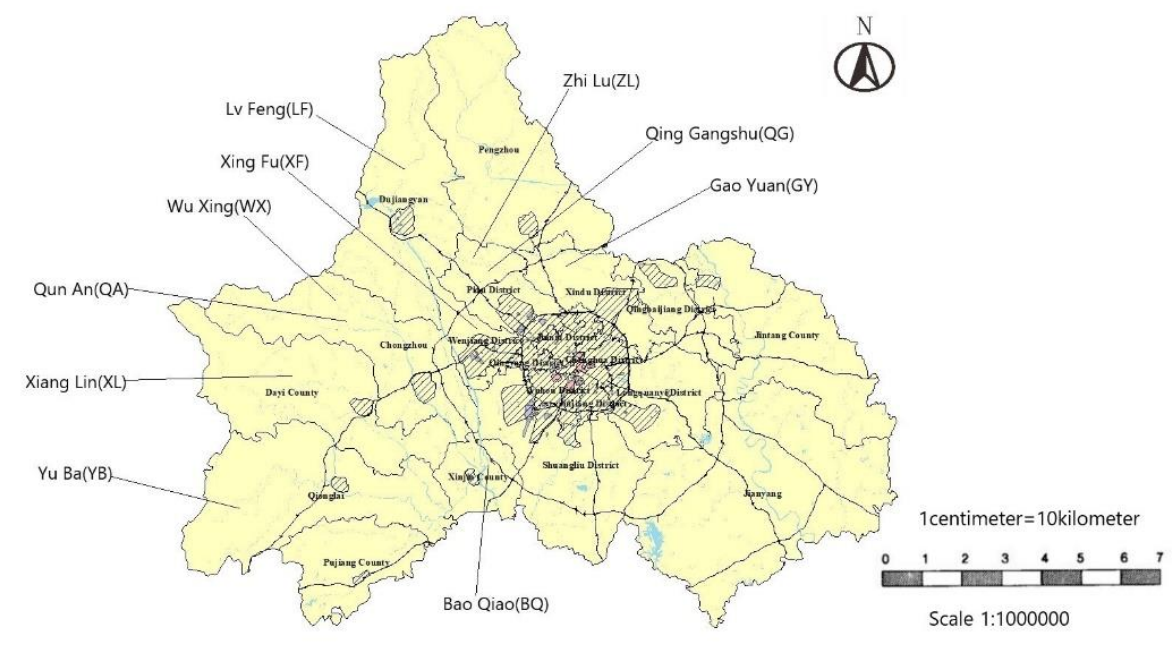

In response to the national campaign of BNSC, in particular, the Chengdu government issued a strategy for rural restructuring in 2011. With an emphasis on the balance between urban and rural development, the government distinguishes Chengdu territory into two domains. For those living nearby an urban or market town area, an increasing concentration of population and intensive use of rural land is proposed. For the rest outside of the planned town or urban area in the near future, a different strategic approach has been posed, namely "small-scale, group-type, micro rural, ecological" (“小规模, 组团式, 微田园, 生态化”, SGME thereafter) in order to achieve balance and harmony between ecological, economic, social and cultural systems at the village level. This paper focuses on the second approach of rural restructuring in the suburban zone of Chengdu (CRDC, 2015).

Chengdu government started the SGME projects in eight pilot villages with a total investment of 833 million yuan in 2012. Since then, the number of involved villages have increased to 28 in 2013 , and to 123 by April 2016. Meanwhile, there is a trend in the growth of farmland transfer. It is estimated that a total of 3.73 million mu farmland have been reallocated to those specialised householders, cooperatives or agribusiness companies, which account roughly to $58.6 \%$ of farmland areas in total across rural Chengdu (CDMG, 2016). Behind the process of farmland transfer and scaling-up operation, new producers' organisations, including: leading enterprises for agribusiness, farmers' cooperatives, and family farms, have 
experienced a rapid growth, and the number of them reached to 542, 6410 and 2,468 respectively by 2015 , according to official data ${ }^{1}$.

There are three types of the SGME projects carried out in Chengdu: comprehensive land management, ecological protection, and village environmental improvement. Comprehensive land management involves land consolidation, reclamation and transfer of not only new housing building and village reconstruction, but also rural land transaction through Chengdu Land Market so that participatory villages and householders can gain the economic compensations from land saving and reallocation. This type of rural restructuring has been popular after the severe earthquake near Chengdu in 2008, which despite the calamities caused, created also an opportunity for the local government to plan and improve the efficiency of land use. The second type of project, the ecological protection in forest areas, aims to protect and maintain local forest and original landscape, the unique heritage of Chengdu where traditional farming and pastoral style homes are based upon. Similar to the first type, this requires a new way of land management such that the upgrade of village living standards and income levels will not damage, but improve ecosystem services and attract external investments and urban tourists. The third type of project is to improve the village environments, such as sanitation, road connection and infrastructure conditions. Compared with the first two types, the third type does not involve any land transfer and new housing so it costs only small amount of government funding without external investment involved. For the theme of this paper, the third type of project is excluded from our discussion.

Having experienced three year pilot projects involving over 500 villages across Chengdu, the second author of this paper was invited by the Chengdu government (via its SGME Programme Committee) to conduct an evaluation project on a number of sample villages. Through negotiations with the authority on the first two types of pilot villages, 10 administrative villages were selected as samples for secondary information collection, participatory observation with the government officials and household questionnaire survey in October 2015. A total of 71 householders participated in the questionnaire survey.

Table 2 provides a summary of sample villages' profiles.

Table 2 Baseline information of sample villages

\begin{tabular}{cccccccc}
\hline Village & $\begin{array}{c}\text { Distance to } \\
\text { Chengdu }(\mathrm{km})\end{array}$ & $\begin{array}{c}\text { Household } \\
(\mathrm{HD}, \text { no. })\end{array}$ & $\begin{array}{c}\text { Population } \\
(\text { no. })\end{array}$ & $\begin{array}{c}\text { Land in } \\
\text { total }(\mathrm{mu})\end{array}$ & $\begin{array}{c}\text { Farmland } \\
(\mathrm{mu})\end{array}$ & $\begin{array}{c}\text { no. HDs in } \\
\text { SGME of HD }\end{array}$ & \begin{tabular}{c} 
involved \\
\hline
\end{tabular}
\end{tabular}

\footnotetext{
${ }^{1}$ http://www.sc.gov.cn/10462/10464/11716/11718/2016/1/8/10364535.shtml
} 


\begin{tabular}{lccccccc}
\hline GY & 39.5 & 818 & 2430 & 4800 & 2660 & 238 & 29.1 \\
WX & 50.0 & 878 & 3066 & 5400 & 3212 & 751 & 85.5 \\
QA & 58.9 & 900 & 2758 & 6750 & 3000 & 318 & 35.3 \\
XL & 64.6 & 1068 & 4128 & 6000 & 3585 & 114 & 10.7 \\
XF & 32.6 & 881 & 2352 & 4648 & 2960 & 472 & 53.6 \\
QG & 27.0 & 932 & 2251 & 3600 & 2065 & 903 & 96.9 \\
ZL & 37.2 & 528 & 1819 & 2899 & 1972 & 438 & 83.0 \\
YB & 114.6 & 780 & 2443 & 13350 & 4670 & 135 & 17.3 \\
BQ & 53.9 & 460 & 1201 & 3988 & 2230 & 30 & 6.52 \\
LF & 56.0 & 766 & 2340 & 4800 & 2826 & 205 & 26.8 \\
\hline
\end{tabular}

Sources: Chengdu government website and collection of the second author.

Notes: $\quad$ SGME- "small-scale, group-type, micro-rural, ecological" project run and made by Chengdu municipal government

From the perspective of the representativeness of sample villages, a number of observations can be drawn from our sampling process, fieldwork methodology, and profiles of sample villages illustrated in Table 2 . Firstly, the sample villages cover all of the three types of topography (plain, hill and mountain); two types of pilot projects: comprehensive land management for eight plain villages and two ecological protection in hill and mountainous villages, as well as the variety of household participation rate from over $95 \%$ at highest to less than $10 \%$ at lowest. Secondly, we do not claim that the sampled villages can represent all pilot villages in Chengdu. This is because the sampled villages is based upon successful cases recommended by the government which are more likely to be located in richer resource endowments areas with more advanced economic development. Equally important is the limitation of our fieldwork methodology as no qualitative method (such as in-depth, semi-structure or group interview) was adopted due to the limits on the duration of time spent in these sample villages.

\section{Data analysis results}

This section presents the data analysis results via five parts: variety of households' participation in land transfer; land transfer and changes of village economic system, land market for residential land saving, case studies on social capital, and the comparison of the patterns in land use decision making.

\subsection{Profiles of sample households and land transfer}

Of the total 71 householders who completed our questionnaire survey from all sample villages, over a half (52\%) call themselves farmers, $38 \%$ mixed between agricultural and non-agricultural activities, leaving $10 \%$ 
for non-agricultural activities only. Matching with the above distribution, furthermore, 125 (or $42.2 \%$ ) out of 297 family members have a non-agricultural residential status. It is very impressive that all of respondents claimed that there is at least one family member who had accessed to higher education. As a result, a total of university students reached to 94 . The above information clearly indicates not only the existence of bridging social capital, referring to social links between sample villages and urban society via both labour and student migration, but also the potential of human capital for rural restructuring via return migration in the future.

The commercialisation of agricultural production and large scale of rural-urban migration have had a profound impact on the countryside. Among the total of 255 labourers, for instance, $35.3 \%$ work for other employers within villages whilst $41.6 \%$ are migratory labour outside of villages. Amongst those migratory labourers, furthermore, 58\% work within the county, and 38\% within Chengdu, leaving less than 5\% going beyond Chengdu. It is also worth noting that the SGME project has had little impact on the distribution of rural labourers within or outside of village, and between agricultural and non-agricultural sectors.

Similar to other villages in Chengdu and beyond, non-agricultural income has dominated household income, accounting to $70 \%$ of total revenues. In relation with SGME project, furthermore, there is a significant growth of household total income from 33,046 yuan to 47,764 yuan, an increase of $44.5 \%$ on the average. Compared with slight increases of agricultural income from 11,528 yuan to 13,816 yuan, in particular, non-agricultural income jumps from 24,745 yuan to 37,607 yuan, an increase of 52\%.

The most significant change related to the SGME project, perhaps, is farmland transfer as summarised at Table 3. Compared with the status before the project, main changes can be highlighted as follows. Firstly, the participation rate of households increased from less than a half (46.5\%) to nearly three quarters (73.2\%). Secondly, the area of farmland transfer each household soared from less 2 mu to 2 to 4 $\mathrm{mu}$, and behind the growth, we can see the soaring of the price towards $1200 \mathrm{yuan} / \mathrm{mu}$ or above. Thirdly, the duration of farmland transfer moved toward middle term (5-15 years) or longer. In addition, compared with the decline of traditional internal transfers (转包), leasing (租贷) had significantly increase which is associated with the increased rate of signed contracts. Nonetheless, we note an increase of non-agricultural use.

Table 3 Participation of farmland transfer among sample households (N=71, \%) 


\begin{tabular}{llcc}
\hline \multicolumn{1}{c}{ Indicator } & \multicolumn{1}{c}{ Item } & Before SGME & Since SGME \\
\hline Participation & Involved HDs in total & 46.5 & 73.2 \\
\hline Area & $<=2 \mathrm{mu}$ & 39.4 & 32.7 \\
& 2 to $4 \mathrm{mu}$ & 36.4 & 48.1 \\
& $>4 \mathrm{mu}$ & 24.2 & 19.2 \\
\hline Price & $<1000 \mathrm{yu} / \mathrm{mu}$ & 42.4 & 34.6 \\
& $1000-1200 \mathrm{yuan} / \mathrm{mu}$ & 30.3 & 34.6 \\
& $>1200$ yuan/mu & 27.3 & 30.8 \\
\hline Duration & $<=5$ years & 21.2 & 15.4 \\
& 5 to 15 years & 42.4 & 50.0 \\
& $>15$ years & 36.4 & 34.6 \\
\hline Formatting & Intra-household transfer & 33.3 & 21.2 \\
& Leasing & 48.5 & 63.5 \\
Purpose & Others & 18.2 & 15.4 \\
& Agriculture & 97.0 & 88.5 \\
Signed contract? & Non-agriculture & 3.0 & 11.5 \\
& Yes & 72.7 & 84.6 \\
\hline
\end{tabular}

Sources: all tables below are based upon our questionnaire survey or information collected from sample villages.

In terms of the factors influencing farmland transfer, Table 4 shows that family livelihood structure and age group of the head of the households are significantly related to the distribution pattern. For farming only households which account just over a half of all respondents, the majority (about three quarters) involved farmland transfer either 2 to 4 mu or more, leaving the rest (one quarter) for the small scale less or equivalent to $2 \mathrm{mu}$. This is in contrast to those in the group of nonfarm household heads who fall into the group of small scale of farmland transfer less or equivalent $2 \mathrm{mu}$. Given the fact that those nonfarm households may have limited areas of farmland, this result seems to suggest that SGME project has bigger impact on those traditional farming households than other groups in terms of farmland transfer to those specialised farming households. Similarly, the project has more impact on older group ( $>45$ years old) than younger group $(<30$ years old).

Table 4 Farmland transfer by household livelihood structure and age group

\begin{tabular}{llcccc}
\hline HD head & \multicolumn{1}{c}{ Item } & $<=2 \mathrm{mu}$ & 2 to $4 \mathrm{mu}$ & $>4 \mathrm{mu}$ & No. HDs \\
\hline By livelihoods & Farming only & $26 \%$ & $37 \%$ & $37 \%$ & 27 \\
& Farm plus other & $25 \%$ & $75 \%$ & $0 \%$ & 20 \\
& Non-farmer only & $100 \%$ & $0 \%$ & $0 \%$ & 5 \\
\hline By age & $<30$ years old & $42.9 \%$ & $57.1 \%$ & $0 \%$ & 7 \\
& 30-45 years old & $36.8 \%$ & $57.9 \%$ & $5.3 \%$ & 19 \\
& $>45$ years old & $26.9 \%$ & $38.5 \%$ & $34.6 \%$ & 26 \\
\hline
\end{tabular}


In light of the format of land transfer, we find a significant growth and domination of land leasing among the group of ordinary households from $62.5 \%$ to $73.8 \%$. This is in contrast to the group of village cadres, over half of which looked to other channels, mainly shareholding, to transfer their farmland.

\subsection{Land transfer, specialised production and social capital}

SGME projects offer new opportunities to reallocate farmland toward scaling-up and concentration to those specialised farmers. Under the constraints of rural land regulation, there are three channels to reallocate farmland: family farm, farmers' cooperative and government approved agricultural business companies or "dragon leading enterprises". Table 5 highlights the latest development of new type of rural producers' organisations and impact of farmland transfer from individual households to specialised farmers.

Table 5 Land transfer (LT) by new producers' organisation in sample villages (mu)

\begin{tabular}{cccccccc}
\hline \multirow{2}{*}{ Village } & \multicolumn{2}{c}{ Family farm } & \multicolumn{2}{c}{ Cooperative } & \multicolumn{2}{c}{ Enterprise } & LT rate \\
& No. & Land & No. & Land & No. & Land & \\
\hline GY & 1 & 55 & 1 & 970 & 4 & 930 & $75.2 \%$ \\
WX & 2 & 170 & 1 & 760 & 2 & 2340 & $100.0 \%$ \\
QA & 5 & 500 & -- & -- & 4 & 500 & $83.3 \%$ \\
XL & 1 & 54 & 2 & 460 & 10 & 2540 & $85.2 \%$ \\
XF & -- & -- & 1 & 1400 & 5 & 557 & $64.2 \%$ \\
QG & 2 & 70 & 1 & 800 & 1 & 70 & $45.5 \%$ \\
ZL & 2 & 70 & 2 & 500 & -- & -- & $28.9 \%$ \\
BQ & -- & -- & -- & -- & 2 & 500 & $22.4 \%$ \\
\hline Total & 13 & 919 & 8 & 4890 & 28 & 7437 & $61.0 \%$ \\
\hline
\end{tabular}

Note: Location and Chinese names of villages are marked in Map 1.

Table 5 shows the variation of farmland reallocation among sample villages is related to the development of new types of producers' organisations. On the average, farmland transfer rate amongst 10 villages is $61 \%$, $4 \%$ higher than the mean of $56.7 \%$ across Chengdu. In general, the scale of farmland transfer is relatively small in family farming (less than $100 \mathrm{mu}$ ) which is carried out mainly via internal transfer with their relatives or neighbourhoods.

Specialised cooperatives involve farmland transfer through two mechanisms: leasing and shareholding. For land leasing, a cooperative in QG Village was established in October 2012 for the purpose of enlarging the scale of oil vegetable plantation with their own brand in market, and also carrying out an 
ecological agricultural experiment involved rice and fish feeding simultaneously. A total of 47 households joined in the cooperative, leading to the transfer of $700 \mathrm{mu}$ farmland to the cooperative. As a return, participatory holders received 2,275 yuan/mu for land leasing in 2015. For land shareholding, "Five Star Land Shareholder Cooperatives" established in WX Village in April 2012 to develop modern agriculture and rural tourism for urban consumers. The membership of the cooperative has increased from 44 households at the beginning to currently 361 households who contribute a total of $952 \mathrm{mu}$ farmland to the cooperative. Compared with family farm, the land transfer for the establishment of cooperatives in both cases above is an indicator of the significant enhancement of bonding social capital during the period of the pilot project.

Dragon-leading enterprises can achieve the integration of fragmented farmland plots by various ways such as leasing, subcontracting, and shareholding. In contrast to family farms or cooperatives, those enterprises represent urban capital which seeks out opportunity to access rural land. Such a process may not be implemented without the introduction and intervention from local government who is in charge of the approval of the project proposed by leading enterprises and also recommend targeted farmland, villages and households for further discussion and negotiation. In comparison to the "voluntary" transfer of farmland from individual households to specialised family farms or cooperatives, inevitably, farmland transfer to those enterprises are more likely to be achieved via government's persuasion and some favourable policies (e.g. securing job opportunities). No less important, mutual trust must be established during the process of the negotiation between the enterprise and villages members, a precondition of signing an agreement between individual farmers and the enterprise.

According to a local informant, successful negotiation and signature of land transfer contracts can rarely be achieved without a consent among village members, which is related to a certain level of bonding social capital to ensure mutual trust and cooperation between village members, local government officers and external investors. For example, the government planned to build a large scale base for modern agriculture and rural tourist base in GY Village which included 1,000 mu for medicine herbs, $400 \mathrm{mu}$ for organic vegetables, $300 \mathrm{mu}$ for Cherry Orchard, and 1,200 mu for quality vegetables. Such an ambitious plan involved a complicated process in terms of discussion, consultation and consent between local government, village committee and individual farmers in terms of land transfer and urban investment. To initiate this project, in fact, the township government selected and invited three agribusiness enterprises to 
negotiate with villagers directly about the price of farmland transfer and their participation in the project. As a result, a total of 2,900 mu of agricultural land have been transferred to those enterprises at the price of 1,500 yuan/mu each year to households. This case indicates the interconnection between bonding and bridging social capital, which may not happen without government intermediation or intervention.

\subsection{Residential land saving and village reconstruction}

For rural restructuring, farmland transfer might not be separated from, but more likely interwoven with, the reallocation and redistribution of residential land. This is because the scope of rural restructuring is not limited to village reconstruction, but also includes the reshape and improvement of non-agricultural land use either within or beyond village territory. For the latter, the process won't happen without a market for rural (non-agricultural) land trade market established in Chengdu and other cities in China. Based upon information collected from 10 villages, Table 6 illustrates roles of the land market in the reallocation and transaction of saving residential land for village reconstruction.

Table 6 Reallocation and transfer of residential land for various purposes

\begin{tabular}{cccccccc}
\hline Village & $\begin{array}{c}\text { Area of land } \\
\text { consolidation } \\
(\mathrm{mu})\end{array}$ & $\begin{array}{c}\text { Area of land } \\
\text { for new village } \\
(\mathrm{mu})\end{array}$ & $\begin{array}{c}\text { Area of land } \\
\text { for trade } \\
(\mathrm{mu})\end{array}$ & $\begin{array}{c}\text { Rate of land } \\
\text { saving }(\%)\end{array}$ & $\begin{array}{c}\text { Year of } \\
\text { land trade }\end{array}$ & $\begin{array}{c}\text { Price of land } \\
\text { trade } \\
\left(10^{4} \text { yuan/mu }\right)\end{array}$ & $\begin{array}{c}\text { Amount of bank } \\
\text { mortgage } \\
\text { (million yuan })\end{array}$ \\
\hline GY & 141 & 58 & 83 & 58.9 & 2014 & 35 & 13 \\
WX & 596 & 245 & 351 & 58.9 & 2016 & 30 & 55 \\
QA & 180 & 60 & 120 & 66.7 & 2012 & 30 & 36 \\
XL & 176 & 155 & 21 & 11.9 & 2014 & 40 & none \\
XF & 314 & 126 & 188 & 59.0 & 2014 & 90 & 50 \\
QG & 411 & 146 & 265 & 64.5 & 2016 & 65 & 68 \\
ZL & 483 & 190 & 293 & 60.7 & -- & -- & -- \\
YB & 150 & 50 & 100 & 66.7 & 2014 & 35 & none \\
BQ & 71 & 15 & 56 & 78.9 & 2015 & 35 & none \\
LF & 237 & 94 & 143 & 60.3 & 2011 & 50 & none \\
\hline
\end{tabular}

Rural restructuring via the SGME project has created an opportunity for relevant villages and householders to not only rebuild new houses and village infrastructure with higher standards, but also save the residential land for other purposes. There are two options adopted by villages to deal with "saving residential land": A) transfer of the area (quote) of saving land to other location within the same township or administrative territory; B) using the quote for the purpose of non-agricultural production or service within the village 
territory. For option A), the differences between the area of land consolidation (referring to the demolition of old households in original residential site) and the area of new houses in new residential site can be used in Chengdu Land Trade Centre (market) so that villages and relevant households can gain financial compensation to cover part or all of the cost of new house building. For option B), village members and leaders can use the saving land quote to attract external investment, bank loan and other business opportunities for village non-agricultural development, infrastructure improvement as well as public service provision.

A number of observations can be drawn from Table 6. Firstly, rural restructuring has led to a big saving of residential land in sample villages, accounting nearly $60 \%$ on average. Secondly, the price of land trade varies greatly from 240,000 yuan/mu to 900,000 yuan/mu, which is related to many factors, including years of trade, geographic location of village as well as the channel of the trade (e.g. through the Chengdu Land Market or via negotiation between villagers and external investors directly). It is worth noting, however, that there is a minimum price for land trade set up by Chengdu Municipal Government to reflect the cost of village reconstruction and protect interests of rural residents. The minimum price is adjusted every year from 180,000 yuan/mu in 2011 to 300,000 yuan/mu in 2014. Thirdly, the benefits of the residential land reallocation and saving are not limited to financial compensation from new land users, but also include the opportunities for villagers to apply for commercial bank loan (mortgage) for new house building project. Such an opportunity cannot be imagined without the high value of saving land as deposit for the bankers. The mechanisms of social capital for land transfer and residential land saving for rural restructuring are discussed in Section 5.4.

\subsection{Roles of social capital in land transfer and rural restructuring: three cases}

It is unlikely that rural restructuring could be successful without the development and use of social capital, referring to the increase of mutual trust and common interests within communities (bonding social capital) and between internal and external members (bridging social capital). Involving government and other capital, following cases illustrate the various role of social capital in rural restructuring.

\section{Case 1: Government-led rural restructuring (H1)}


A common feature of rural restructuring across China is government initiative or leading not only in the selection of villages and land use planning for production and residence, but also financial inputs and favours policies to mobilise internal and external investments. As a predominant pattern among 10 sample villages, the government-led rural restructuring and contribution from social capital can be illustrated as $\mathrm{XF}$ village case below.

$\mathrm{XF}$ village is an urban-urban fringe village which is passed through by a major road. As the first cohort of the SGME project, this village was selected by the local government in 2011 to develop an "ecological tourism resort", with aim to promote land consolidation, new village construction and industrial development, and to create garden wetlands and western Sichuan style folk houses. Following the government plan, the village organisation is in charge to mobilise village members to participate in land transfer and make contribution to the development of tourist industry. A series of consultation meetings held with village members for land use planning and decision making, associated with the share of financial costs.

The implementation of the SGME project in this village was divided into two phases. The first phase involved six village groups, 236 households, $1390 \mathrm{mu}$ farmland and $142.1 \mathrm{mu}$ residential land. Based upon a process of discussion, consent was reached among all involved households for a strategic plan for village reconstruction and development. According to this plan, the new residential site occupied $58.5 \mathrm{mu}$ and saved land of $83.6 \mathrm{mu}$ residential land were used in two ways. First, savings of residential land itself use were two ways: The first half, $42.5 \mathrm{mu}$, was traded in the land market to compensate the part of costs of building new houses. The second half, $41.1 \mathrm{mu}$, was used to initiate and develop a tourist business by establishing a XF Investment Shareholding Corporation, and all households became shareholders of this company. Based upon the second piece of non-agricultural land quote and the registered company, organised villagers managed to promote and attract external investors for a cooperative development of local tourist resources. As a result, XF Investment Corporation and Shanghai Star Group jointly set up a Chengdu Tourism Resources Development Co., Ltd., to develop joint business plan and promotion to attract external investors to participate in this project. So far, a total of 123 million yuan external funding has been arrived for joint investment on a tourist complex. 
This case illustrates that under the government planning and guidance, how the village organisation carried out a process of consultation and discussion among village members, leading to residential land saving and transfer via Chengdu Land Trade Centre (land market) for new infrastructure (building new houses) on the one hand, and the development of both bonding social capital (establishing a shareholding company) internally and bridging social capital (partnership with external investor to attract more external investment and successful initiative of new livelihood (rural tourism business). Similar to GY, XL, YB, LF villages, this case confirms the hypothesis (H1) posted in Section 3: the role of local government in initiating and facilitating the interconnection and co-development between bonding and bridging social capital, an important condition for the success of rural restructuring.

Case 2: Farmer self-initiative and organising rural restructuring $(\mathrm{H} 2)$

A dilemma facing rural restructuring in China is the lacking of balance or interface between government intervention and grassroots innovation as the top-down approach often ignores the needs, potential and creativity within rural communities, leading to the failures of many projects (Zhang and Wu, 2018). In this regard, ZL village is a good case not only because it sheds new light on the role of social capital in rural restructuring, but more importantly, it demonstrates how the government programme (SGME) can be developed based upon farmer-led innovation practice.

$\mathrm{ZL}$ village was a famous place in the region due to its long history in both cage crafts and green chives planting. Despite having a higher individual household income (13,225 yuan compared with the average of 9,898 yuan per capita in rural Chengdu in 2011), the villagers were scatted in 10 natural villages with poor infrastructure, lack of public services and interaction space. The backward infrastructure was mainly caused by the absent of village collective economy. Learning from the successful experience of village reconstruction in other places outside of Chengdu, new leader of the village, Mr. Sun who is also a returned entrepreneur, arranged more than 50 meetings with different groups and village members to gain a consent about the future of village development. It resulted in an action plan to establish a ZL Village Collective Asset Management Co. Ltd, to reallocate collective land (mainly residential land) for village reconstruction and industrial development. More than $80 \%$ of villagers agreed the proposal and joined the company as founding members, leading to a successful initiative and sustainable process of rural 
restructuring. The key elements for this successful project, according to ZL villagers own interpretation, are the "five selves-":

- Self-finance: all participants contributed 10,000 yuan deposit per household to initiate the project rather waiting for government funding or bank mortgage for village construction;

- Self-decision making: all plans and engineering programmes, such as comprehensive land management plan, new house construction, land reclamation, were discussed and approved by all villagers before the implementation;

- Self-construction (or management): all building projects were fully controlled and managed by villagers through their selected project management team (15 members) and monitoring team (6 members);

- Self-development (or sustainable development). Not limited to new housing and infrastructure development in new village location, saving residential land (293.4 mu) has been used for cage manufacturing complex and rural tourism and a total of $1500 \mathrm{mu}$ farmland has been transferred for the establishment of a green chives cooperative, leading to a great enhancement of local pillar industries; and

- Self-distribution: all participants are entitled to share the benefits from the land reallocation and development of collective economy based upon their contribution in terms of land, capital and labour.

The successful case of ZL Village has been recognised by the Chengdu Municipal Government as a model of SGME project in 2012. In the government document, it encourages farmers in pilot project villages to explore their own way of land transfer and to establish collective asset management companies for village reconstruction. Different from Case 1, this case starts from the new leadership (human capital) who mobilised and concentrated on all village members' participation and consent (bonding social capital) to share responsibility in investment (financial capital) and management of village development. Many sample villages such as QG, WX share the pattern with ZL village in terms of the development and enhancement of bonding social capital at the beginning of rural restructuring, leading to the establishment and development of village collective economic organisations, a sound foundation of community cohesion and 
sustainable development. The case confirms the hypothesis (H2): farmer self-initiative and organising process results in upgrading social capital for successful project design and implementation.

Case 3: Returned entrepreneur-oriented rural restructuring (H3)

Rural restructuring is not necessarily dependent upon the development of bonding social capital first. This case presents an alternative way through bridging social capital to initiate a process of rural restructuring. The key person of this case is Ms. Hou Jing, a member of a hill village of BQ. As one of the successful migrant entrepreneurs (similar to Mr. Sun in Case 2), Ms. Hou and her husband have not only learnt new knowledge, skill, confidence and competence to conduct their own business in urban China, but also accumulated a large amount of capital as well as extended social network for business investment.

Having seen the opportunities emerging from the SGME project, Ms. Hou and her husband decided to return to their home village and make an investment to a forest protection project there. This project includes a number of elements: 1) relocating 54 scatted households into a new residential place to save a total of 56 mu residential land for the use of tourist business; 2) leasing $400 \mathrm{mu}$ forest land from those villagers to plant economic trees such as silver blue flowers, ailanthus, catalpa and others; 3) allowing villagers to plant some of vegetables, mushrooms between trees in the rented land without any charge; and 4) giving priority to recruit villagers in his company. The total cost of this project was 32 million yuan, of which 19.6 million or $61.25 \%$ was used for village reconstruction including building new houses for those resettled households as well as infrastructure and public service facilities in the new residential place.

The case above was supported by not only local government but also all of the 54 households in the area of the planed land who can gain many benefits from this project, including: freedom to move to new houses with better living conditions and public services provision, secured incomes from rental farmland, vegetable plantation for rural tourists, as well as salaries from employment from Ms. Hou's business. As a result, the land transfer project initiated by a returned entrepreneur has brought a new momentum for community building and village development.

This case is significant for rural restructuring in China taking into account both challenges facing hundreds of millions migrant workers in terms of integration into urban society and also the shortage of various capitals (labour, financial and talent) in its countryside. It indicates that return migration, a process 
of interconnecting and transferring of bridging social capital with other capitals, provides a new momentum for rural restructuring.

All three cases above contain some common elements which are interconnected or interwoven with each other, including: 1) trust, democratic discussion and consent, leading to collective action (bonding social capital); 2) land transfer and effective use in both farmland and residential land (natural capital); 3) new opportunity for investment (financial capital) either or both internally (via cooperative) and externally (via dragon enterprise); 4) return entrepreneurship to initiate rural restructuring (interlinked between social and human capitals in Cases 2 and 3); not less importantly, 5) participation from and fair distribution of project benefits among village members (community building), a sound base for the integration of all capital. As a result, land transfer projects in those villages trigged a process of opening, empowering and consolidating the community for better use of external resources, markets and capitals, leading to a balanced account and shared benefits from land transfer and rural restructuring. It is worth to note, three types of rural restructuring, government-led, farmer self-organised and returned entrepreneur-oriented process, are not totally distinguished from each other, and a certain overlapping can be founded between them. 
The three cases above highlight the importance of social capital in rural restructuring and land transfer, which varies with sample villages. From the perspective of sustainable livelihood framework, according to Scoones (2009), farmers' land use decision making can be analysed from three connected components: livelihood platforms (assets), livelihood strategies (activities choices) and livelihood outcomes (well-being). Applying the evaluation framework posed in Section 3, Table 7 provides a comparison between different patterns or cases in terms of platforms, strategies, and outcomes with an emphasis on the roles of social capital and government intervention.

Table 7 Comparison of livelihood assess, strategies and outcomes of land transfer decision making

\begin{tabular}{|c|c|c|c|c|}
\hline Pattern (case) Assets & Social capital & Government & Strategies & Outcomes \\
\hline $\begin{array}{cl}\text { Government }- & \bullet \text { Access to main } \\
\text { led }(\mathrm{XF}) & \text { road \& subway } \\
\bullet & \text { Rural urban } \\
& \text { fringe }\end{array}$ & $\begin{array}{l}\text { - Trust: villagers and } \\
\text { village organiser } \\
\text { - Shareholder Ltd } \\
\text { - Partnership with } \\
\text { external investors }\end{array}$ & $\begin{array}{l}\text { - Regional land use } \\
\text { plan \& policy } \\
\text { - Residential land } \\
\text { saving and trade } \\
\text { - Gov. funding } \\
\text { - Support investment }\end{array}$ & - Rural tourism & $\begin{array}{l}\text { - H income \& living standards } \\
\text { - Diversity of income } \\
\text { - Upgrade: ecosystem \& } \\
\text { public services } \\
\text { - } 54 \% \text { of HDs involved }\end{array}$ \\
\hline $\begin{array}{ll}\text { Farmer self } & -\bullet \text { Cage history } \\
\text { organising } & \bullet \text { High saving } \\
(\text { ZL }) & \bullet \text { Leadership }\end{array}$ & $\begin{array}{l}\text { - Fully debate and } \\
\text { participate } \\
\text { - Commitment of all } \\
\text { villagers } \\
\text { - Shareholder Ltd } \\
\text { - Shared responsibility }\end{array}$ & $\begin{array}{l}\text { - Less government } \\
\text { Intervention } \\
\text { - Residential land } \\
\text { saving and trade } \\
\text { - Model for whole } \\
\text { programme }\end{array}$ & $\begin{array}{l}\text { - Scaling-up of craft } \\
\text { industry } \\
\text { - Internationalised } \\
\text { rural tourism }\end{array}$ & $\begin{array}{l}\text { - H income \& living standards } \\
\text { - Balance: } 1^{\text {st }}, 2^{\text {nd }} \& 3^{\text {rd }} \\
\text { industries } \\
\text { - Upgrade: ecosystem \& } \\
\text { public services } \\
\text { - } 83 \% \text { of villagers } \\
\text { participation } \\
\end{array}$ \\
\hline $\begin{array}{ll}\text { 3. Returned } & \bullet \text { Forestry area } \\
\text { entrepreneur } & \bullet \text { Tourism nearby } \\
\text {-oriented } & \bullet \text { Transport } \\
(B Q) & \text { access }\end{array}$ & $\begin{array}{l}\text { - Bridging social } \\
\text { capital for return } \\
\text { entrepreneur \& } \\
\text { investment }\end{array}$ & $\begin{array}{l}\text { - Land use plan } \\
\text { - Support investment }\end{array}$ & $\begin{array}{l}\text { - Land leasing } \\
\text { - Job opportunities }\end{array}$ & $\begin{array}{l}\text { - H income \& living standards } \\
\text { - Diverse income } \\
\text { - Upgrade: ecosystem \& } \\
\text { public services } \\
\text { - } 6.5 \% \text { of HDs involved }\end{array}$ \\
\hline
\end{tabular}

A number of observation can be drawn from Table 7. Firstly, all three cases are unique or advantage in one or more capital endorsements: physical, natural, human, financial and cultural capital. Secondly, in relation with different conditions, livelihood strategy varies with village: the development of rural tourism as new source of village income in addition to cash cropping in Case 1 (XF village); scaling-up of cage craft manufacturing industry instead of small cage craftworks plus the development of international tourism to promote traditional culture in Case 2 (ZL village); new income source from land leasing plus agricultural empowerment opportunity to replace subsistence agriculture in Case 3 (BQ village).

Thirdly, the role of social capital varies in terms of formatting and determining the success of land transfer decision making. The mutual trust between village organisation and participatory householders is 
a key for the establishment of land shareholder company and then partnership with external investor for rural tourism in Case 1. More than mutual trust and commitment of village organisation, social capital in Case 2 has been greatly developed and enhanced through fully debate, participation and shared responsibilities in project design and implementation, leading to self-finance and high cohesive community. In contrast, bridging social capital is used in Case 3 to attract the return migration and investment from the outside.

Fourthly, it is vital for all cases that government land policies including the balance of "increase" and "reduce" farmland and also the policy for land transfer trade in Chengdu Land Trade Centre give a space for village leaders and community organisation to plan and better use collective land for rural restructuring. In relation to different conditions (assets) and role of social capital, furthermore, the role of government intervention is significantly different village by village. Compared with full involvement and support from local government in Case 1, less government intervention and financial support in Cases 2 and 3 leave more space for returned entrepreneurs to initiate a bottom-up development.

Finally, all cases have positive outcomes or impacts in terms of developing and securing income from the $2^{\text {nd }}$ (manufacturing) and $3^{\text {rd }}$ (rural tourism) sectors, sustainable use of land resources, significant improvement of livening standards and the access to the public services. It is worth to note that no all of village members participate in or be beneficial from this project. The variation in the participatory rate from $83 \%$ (Case 2), 54\% (Case 1) and 6.25\% (Case 3) raises the question about the criteria for the selection of the project location and fair distribution of public resources/government funding across the countryside.

\section{Discussion and conclusion}

Linking with research questions at the beginning of this paper about the role and contribution of social capital to on-going rural restructuring in China, this section summarises research findings, theoretic contribution, policy implications and limitation of this paper.

\subsection{Combination and interaction between land transfer and community building}

The central issue or challenge facing researchers and campaigners in China's rural revitalisation is in our view to understand the relationship between land transfer and community building, a key for not only sustainable rural livelihoods at household and village levels, but also ensuring shared benefits with all 
stakeholders, in particular all community members involved project. While the overwhelming attention is paid to land transfer for infrastructure upgrading and economic growth in the countryside, community building (the development and enhancement of collective identity, value, vision and confidence of all community members) is largely ignored in the debate, which may have a negative impact from the perspective of social inclusion. In this regard, this paper fills this gap by linking land transfer with demographic profiles as seen in the ten sample villages. A number of observations can be drawn from this research.

Firstly, pilot projects since 2011 have little impact on the trends of village decline at Municipal level and outflow of young talents at village level. For instance, the number of administrative villages in Chengdu is continuous decline from 1975 in 2010 to 1911 in 2015 (CDSB, 2015), a process of destructive and painful relocation for many rural residents. The demographic change in Chengdu and sample villages seems to suggest that rural revitalisation and rural decline are two sides of the same coin. In other words, not all villages have chance to survive or be revitalised on the one hand, and many rural householders may be suffering from this process on the other although we don't have evidence to support it. Among many factors influencing the selection of villages to participate in rural restructuring, the change of community profiles is an important one.

Secondly, our research shows that neither is all community members within sample villages falling into the area of government defined projects, nor is all community members within the government defined area willing to participate in the project or the share of initial costs/investments. As result, of 10 sample villages the rate of villagers' participation shown in Table 1 varies greatly from $96.9 \%$ in QG village to only $6.52 \%$ in BQ; a half of sample villages below $50 \%$ and only three over $80 \%$. One of important factors contributing to such variation is related to a principle in the SGME programme guidance which emphasises on the respect to villagers' willing and consent for collective action, which provides not only a space for the development and enhancement of social capital but also the differentiation between the SGME projects in Chengdu and rural restructuring programmes in many of other locations. The great variation in the participatory rate between villages, however, also raises question to the criteria of selection of villages, and fair distribution or equal opportunity for all villages to access to the government/public funding. 
Thirdly, the pilot projects offer a good opportunity for these community members to discuss what is the future of their villages, and how to better use their land resources, both farmland and residential land, to initiate an innovative project (e.g. rural tourism) alongside upgrading residential conditions and village infrastructure.

Fourthly, the success or failure of rural revitalisation via the interaction between land transfer and community building can be measured by an objective index, sustainable livelihoods for all community members in assigned villages. In this regard, the conceptual framework developed in this paper offers a criterion to examine the extents to which a government-led rural restructuring programme is successful or not in future evaluation project design and implementation.

\subsection{Triangular relationship between social capital, government intervention and other capitals}

The interaction between land transfer and community building in sample villages calls for a novel understanding on social capital, which "enable people to act collectively" (Woolcock and Narayan, 2000: 225), a key for the successful community building and land transfer. Based upon the collection and analysis of information from ten sample villages in Chengdu, we pose a triangular model for the relationship between social capital, government intervention, and other capitals. The necessity and contribution of this model to the debate of rural restructuring can be drawn from following research findings.

Firstly, social capital as mutual trust and combination of bonding and bridging community ties provides a sound foundation for successful community building and land transfer projects. In other words, rural restructuring via land transfer is a process of development and enhancement of social capital, leading to increasing trust, confidence and common interest among community members for collective actions. The evidence of social capital enhancement can be seen from not only the development of collective shareholder companies in many villages, but also the agreement and joint action for residential land saving and village reconstruction in all sample villages.

Secondly, social capital is also important to attract, and develop long term and stable cooperation with, external investors. Cases 1 and 3 indicate that bridging social capital between community members and external investors provides an additional channel to attract talents, technology and capital from the outside. 
Thirdly, the triangular model emphasises on the nature of interdependence and mutual benefits among multiple stakeholders including participatory householders, local government agencies, external investors and others such as urban professionals and consumers' representatives. By establishing ZL village (Case 2) as a "model" of rural restructuring for all pilot projects, actually, Chengdu government has encouraged, and provided institutional support to, villagers' participation and fully expression of their interests and considerations, leading to an enhancement of social capital, a sound base for the consent among community members on the project design and effective implementation afterwards.

The success of "farmer's self-organising" rural restructuring (Case 2) and its contribution to the government programme in Chengdu provides a hard evidence about the necessity and feasibility of bottomup development and interface with government intervention. Furthermore, it also confirms the research findings from an early study on farmer self-organising innovation in Loess Plateau (Wu, 2003; Wu and Pretty, 2004; Wu and Zhang, 2013) and recent researches on rural revitalisation in the world (Li, et al., 2019) and farmer innovation diffusion via government intervention in China (Zhang and Wu, 2018; Zhou, et al., 2019).

The emphasis on the social capital and complementation with the government intervention in this paper does not mean less importance of other capitals, especially financial and human capitals from the outside. Rather, the triangular model is to stress the nature of interdependence between government intervention, social and other capital in which social capital is a key to understand why a bottom-up process can happen in rural China and where is interface with top-down government intervention.

\subsection{Social capital in land transfer and community building: evaluation framework and three patterns}

Based upon the triangular model, we have modified the sustainable livelihood framework (DFID, 1999; Scoones, 2009 ) for the purpose of the evaluation of the government SGME project, leading to an evaluation framework, a useful tool for the analysis of land transfer decision making posed in Section 3. The function and potential of the evaluation framework are illustrated from its application in Section 5.5 (Table 7), which shows how social capital and government intervention plus other capital influence rural livelihood strategies and outcomes.

Applying the evaluation framework to analysis and compare three cases collected from the pilot project, in particular, we can identify three patterns (or channels, pathways) with different conditions and 
constraints for the role of social capital in land transfer and community building. In reflection to the hypotheses posted in Section 3, research findings and contribution to the debate of rural revitalisation can be summarised as follows.

Firstly, government-led rural restructuring in Case 1, representing a dominant pattern among sample villages in Chengdu, emphasises the initiative and determining role of government agencies in the project design, resource distribution and integration, attraction and coordination for external investment. Government-led projects, however, do not expel but complement social capital to ensure fully participation of community members in the process of discussion and consultation, leading to a consent and joint action in land transfer and shared benefits. It seems that government-led pattern is more effective in urban-urban fringe area or location which is more tractive to external investments and also meet the needs of urban consumers. This is because the role of government in the blueprint of the project and also the initial funding on infrastructure improvement is vital to build-up and develop the confidence for both community members within the selected villages and external investors to develop a joint investment framework for the future of successful project and sustainable community development.

Secondly, farmer self-initiative and organising rural restructuring in Case 2 highlights the intrinsic dynamics and innovative potential within some of villages in Chengdu in terms of self-design, consultation/debate, decision-making and implementation of land transfer and rural restructuring including physical (infrastructure), economic (new livelihood system) and social (upgraded trust, shared responsibility and identity) aspects. With the characteristics of less government intervention and contribution except the favourable policy for land transfer and trade in the land market, this pattern shows the importance of upgrading social capital for successful land transfer and community building on the one hand. On the other hand, it could be very difficult to duplicate this pattern due to many unique conditions before the project can start, including unique and strong cultural capital (long history and regional reputation of cage crafts), high income level of individual households, and strong and commitment leadership.

Thirdly, similar to Case 2, returned entrepreneur-oriented pattern in Case 3 shows a new trend and momentum for rural restructuring driven by return migration and entrepreneurship in China in the near future. In contrast to government-led and farmer-self initiative discourses, this pattern emphasises the role 
of human capital via bridging social capital in mobilising and integrating external capitals (including funding, credit, technology and talents) into land transfer and community development. Comparing with low level mutual trust between external investors and village community members in the government-led model, bridging social capital of a returned entrepreneur could have a better chance to interconnect and integrate bonding social capital, leading to successful land transfer and community building. In terms of geographic locations, it seems that this pattern is more suitable for the remote and relatively poor areas where rich natural resources, poor infrastructure and government financial resources may not be enough to attract big investment, leaving a space for return migration and entrepreneurship for home community development and village reconstruction.

It is worth noting that preliminary findings presented above needs more evidence and empirical researches to support it.

\subsection{Policy implementations, limitations and direction of further research}

A number of policy implications can be drawn from above research findings. First, rural restructuring as a process of the interaction of land transfer and community building calls for an opening-up rural communities in order to attract more return migrants and urban investors to make a joint effort with villagers to accelerate rural economic and social development. So it is adapt to consider how to encourage urban investors and interested groups to work closely with and integrate into rural communities for sustainable land use and rural development.

Second, successful land transfer and rural revitalisation cannot be achieved without the development of common interests amongst multiple stakeholders including smallholder farmers, village collective organisations, local government agencies and external investors to reduce the risk of external investment. Along this line, we call for a development of the evaluation framework posted this paper to account for and measure the increase of the common interests of all stakeholders. In this regard, an index system needs to be developed based upon an empirical research.

Third, among other capital, the most important one for successful land transfer and rural restructuring is perhaps new leadership, who can bring new ideas, visions and opportunities into rural communities. Instead of just thinking to attract return migration and entrepreneurship among migrant workers or 
university students/graduates, this paper offers insights into the paired relationship between social and human capital for sustainable land transfer and rural development. Therefore, we call for an emphasis and addition of social capital into rural entrepreneurship education and training programmes.

There are many limitations in this paper. Firstly, the selection of same villages for evaluation resulted from a negotiation with the government office, resulting in a sampling bias to those with good conditions in terms of resource endorsement, economic development and proven track records in other projects. Secondly, the methodology of the fieldwork was the combination of secondary information and household questionnaire survey, leaving little space for the collection of qualitative information owing to the tight schedule (we were limited to spending only a day per village).

Further research direction is suggested to compare between government-led and farmer selforganising land transfer and rural restructuring on the one hand, and the ned to conduct a comprehensive survey on the role of return entrepreneurship in sustainable land use and industrial development on the other (Cheng, et.al., 2019; Zhou, et al., 2019).

\section{References}

Ahlers, A. L. 2015. Weaving the Chinese dream on the ground: Local government approaches to "newtyped" rural urbanisation, Journal of Chinese Political Sciences, 20: 121-142.

Ahlers, A. L. and Schubert, G., 2009. 'Building a new socialist countryside': Only a political slogan? Journal of Current Chinese Affairs, 38(4): 36-62.

Ahlers, A. L. and Schubert, G., 2015. Effective policy implementation in China's local state, Modern China, 41(4): 372-405.

Chen, A., and Gao, J., 2011. Urbanisation in China and the coordinated development module-The case of Chengdu, The Social Science Journal, 48: 500-513.

Cheng, M.Y., Liu, Y.S., and Zhou, Y. 2019. Measuring the symbiotic development of rural housing and industry: A case study of Fuping County in the Taihang Mountains in China, Land Use Policy, 82: 307-316.

Chengdu Statistics Bureau (CDSB), various years. Chengdu Statistics Yearbook, 2001, 2009, 2011, 2015 (in Chinese), Beijing: China Statistical Press.

Chengdu Municipal Government (CDMG), 2016. Annual Report of Chengdu Municipal Government (in Chinese) at: http://www.sc.gov.cn/10462/10464/11716/11718/2016/1/8/10364535.shtml.

Chengdu Rural Development Committee (CRDC), 2015: SGME Projects: challenges and countermeasures, an internal government report (in Chinese). 
de Haas, H. 2010. Migration and development: A theoretical perspective, International Migration Review, 44(1): 227-264.

Department for International Development (DFID) 1999. Sustainable Livelihoods Framework, London: DFID.

Lan, H., Zhu, Y., Ness, D., Xing, K. and Schneider, K., 2014. The role and characteristics of social entrepreneurs in contemporary rural cooperative development in China: case studies of rural social entrepreneurship, Asia Pacific Business Review, 20(3): 379-400.

Li, Y., Liu, Y., Long, H. and Cui, W., 2014. Community-based rural residential land consolidation and allocation can help to revitalize hollowed villages in traditional agricultural areas of China: Evidence from Dancheng County, Henan Province, Land Use Policy, 39: 188-198.

Li, Y.H., Jia, L.R., Wu, W.H., Yan, J.Y., and Liu, Y.S., 2018. Urbanization for rural sustainability: rethinking China's urbanization strategy, Journal of Cleaner Production, 178: 580-586.

Li, Y.H., Westlund, H, and Liu, Y.S. 2019. Why some rural areas decline while some others not: An overview of rural evolution in the world, Journal of Rural Studies, 68: 135-143.

Liu, Y., 2018. Introduction to land use and rural sustainability in China, Land Use Policy, 74: 1-4.

Liu, Y.S. and Li, Y.H., 2017. Revitalize the world's countryside, Nature, 548:275-277;

Liu, Y.S., Liu, Y., Chen, Y.F., and Long, H.L. 2010. The process and driving forces of rural hollowing in China under rapid urbanisation, Journal of Geographic Sciences, 20(6): 876-888.

Long, H.L., Tu, S.S., Ge, D.H., Li, T.T. and Liu, Y.S., 2016. The allocation and management of critical resources in rural China under restructuring: Problems and Prospects, Journal of Rural Studies, 47: 392-412.

Looney, K. E., 2015. China's campaign to build a new socialist countryside: Village modernisation, peasant councils, and Ganzhou model of rural development, The China Quarterly, 224: 909-932.

Putnam, R.D. 1995. Bowling along: America’s decline of social capital, Journal of Democracy, 6(1): 6578.

Putnam, R.D. 2000. Bowling Along: the Collapse and Revival of American Community, New York: Simon $\&$ Schuster.

Scoones, I. 2009. Livelihoods perspectives and rural development, The Journal of Peasant Studies, 36(1): 171-196.

Su, M. 2009. China's Rural Development Policy: Exploring 'The New Socialist Countryside', Boulder, CO: First Forum Press.

Teilmann, K. 2012. Measuring social capital accumulation in rural development, Journal of Rural Studies, 28: 458-465.

Thøgersen, S., 2011. Building a new socialist countryside: Model villages in Hubei, in Alpermann, B. (ed), Politics and markets in Rural China, London and New York: Routledge, 172-186.

Woolcock, M. and Narayan, D. 2000. Social capital: Implications for development theory, research and policy, The World Bank Research Observation, 15(2):225-249.

Woods, M., 2005. Rural Geography: Processes, Responses and Experiences in Rural Reconstructing, London, Thousand Oaks and New Delhi: Sage. 
Woods, M., 2009. Rural geography, In Kitchin, R., Thrify, N. Eds., International Encyclopaedia of Human Geography, vol. 9. Elseview, Oxford, pp. 429-507.

Wu, B., 2003 Sustainable Development in Rural China: Farmer innovation and self-organisation in marginal areas, London and New York: Routledge.

Wu, B. and Liu, L.H. 2019. Bridging social capital as a resource for rural revitalisation in China? A survey of community connection of university students with home villages, forthcoming.

Wu, B. and Pretty, J., 2004. Social connectedness in marginal rural China: The case of farmer innovation circles in Zhidan, north Shaanxi, Agriculture and Human Values 21: 81-92.

Wu, B. and Zhang, L.Y., 2013. Farmer innovation diffusion via network building: a case of winter greenhouse diffusion in China, Agriculture and Human Values 30: 641-651.

Ye, X., 2009. China's urban-rural integration policies, Journal of Current Chinese Affairs, 38(4): 117-43.

Zhang, L.Y. and Wu, B. 2018. Farmer innovation system and government intervention: An empirical study of straw utilisation technology development and diffusion in China, Journal of Cleaner Production, 188: 698-707.

Zhou, Y., Guo, L.Y., and Liu, Y.S. 2019. Land consolidation boosting poverty alleviation in China: theory and practice, Land Use Policy, 82: 339-348. 